\title{
Dementia and literature
}

\section{Christopher A. Vassilas}

\begin{abstract}
As we doctors are beginning to understand more and more about dementia, the public has become increasingly aware of the condition and in turn this has been reflected in the arts. This article discusses four books whose main focus is the experience of dementia, each written from an entirely different perspective: a novel giving a first-person account of dementia by the Dutch writer J. Bernlef; a biography of the famous novelist Iris Murdoch by her husband John Bayley; Linda Grant's account of her mother's multi-infarct dementia (which also describes Jewish migration to the UK two generations ago); and Michael Igniateff's autobiographical novel Scar Tissue. Such accounts, offering insights into how patients and carers feel, cannot but help make us better doctors.
\end{abstract}

This paper continues the series on literature and psychiatry. Previous papers introduced cognitive linguistics and metaphor (Eynon, 2002), literature and substance misuse (Day \& Smith, 2003), death and dying in literature (Skelton, 2003; invited commentaries by Sims, 2003, and Murray Parkes, 2003) and autobiographical narrative and psychiatry (Oyebode, 2003).

There is an increasing awareness among the general public of the terms dementia and Alzheimer's disease. This is reflected in the arts, with the recent release of Richard Eyre's film Iris, based on the book of that name (Bayley, 1998), and with several major authors having recently published books exploring the experience of dementia. I have selected four of these books which give an insight into the devastating condition of dementia from differing perspectives. Two are fictional works: Out of Mind by J. Bernleff (1988) and Scar Tissue by Michael Igniateff (1993); the latter is an observational account of a mother's decline and could be described as an autobiographical novel. Two are non-fictional accounts: John Bayley's book Iris has more of the elements of a conventional biography, whereas Remind Me Who I Am, Again by Linda Grant is a biography both of her mother and of a generation of Jews that fled the pogroms in Eastern Europe for a better life in the West.

\section{Out of Mind}

J. Bernlef is the pseudonym of the Dutch novelist and poet Hendrik Jan Marsman, whose novel Out of Mind (Bernlef, 1988) is now out of print in the UK, but when published in the Netherlands in 1984 it established his reputation. The book is written in the first person and is said to have been influenced by William Faulkner's 1929 novel The Sound and the Fury, part of which is narrated in a stream-ofconsciousness manner by a boy of low IQ. Out of Mind is the most imaginative and difficult of the works I discuss here. Bernlef has thought himself into the mind of a 74-year-old man who suddenly develops cognitive impairment and rapidly deteriorates over what seems to be a short period. Whereas authors such as Grant and Ignatieff go out of their way to talk about the scientific aspects of dementia, Bernlef gives an impressionistic, first-person account. The book is interesting because, like all novels, it needs coherence in order to communicate to the reader yet it attempts to illuminate how a disintegrated mind works.

How does Bernlef approach this task? He gradually describes the breakdown of his protagonist Maarten, a Netherlander living with his wife Vera in the USA. There is no way we can be sure of the validity of his account, but judging from the glimpses we get from our own patients of how they feel and think, his story rings true.

Over one winter Maarten experiences a disintegration of his mental faculties. Initially, there are small lapses: he realises that it is afternoon and he had thought that it was morning; he lets his coffee grow cold, not realising this until his wife points it out. He knows that his memory is failing, but initially believes that 'it's part of old age'. However, during the first few pages of the book it becomes clear to us that Maarten does not have a full understanding of what is going on around him. One morning he finds that he cannot get out of the house; realising that the doors are locked and that 
he cannot find his keys, he gets a hammer and screwdriver and prises the front door open. The logicality of his actions is quite clear: he has encountered a problem and found what he believes is the best solution for it. He goes for a walk with his dog and believes that he must attend a meeting in a certain house; the house that he approaches is empty and he breaks in. Suddenly he realises that he should not be in the house and that he has done something wrong by breaking in.

There is an inexorable decline as the illness progresses. People he sees in the town become mixed up in his mind with people he knew many years ago. Deeper into the book, on the advice of a doctor, Vera takes out a photograph album to show Maarten. The photos trigger memories of the past, of the Second World War and life in occupied Holland, that he shares with his wife. However, this is just a temporary respite, and he begins to believe that he is in his childhood home back in Europe. Later on in the book, his carer again produces a photograph album, but as the illness has progressed he can hardly recognise any of the figures. The carer presses, and again memories of life in Holland during the war are released, but it is as if he does not know where they are coming from.

When the doctor calls for the first time to assess Maarten we see things entirely from Maarten's viewpoint. Although he is clearly an intelligent man he simply does not know who the doctor is, despite being introduced to him, or why he is there. Throughout the book Maarten strives to discern meaning in the world. He finds it, but it is mediated by his dementia and fluctuates from minute to minute. We get a powerful sense of how Vera is struggling with Maarten's illness.

The text does not give Maarten's diagnosis, but he seems to have a rapidly progressive dementia, perhaps of a vascular type with periods of unexpected deterioration and sudden onset. The narrative does not have a regular pace but, like his illness, lurches from situation to situation with events suddenly erupting. For instance, when Maarten wants to let the dog into the house he breaks a window for it. Nevertheless, even as he becomes more severely impaired he can momentarily understand what is going on, as when he overhears Vera talking about him and his illness. Elements of his life are remembered in fragments: we learn about his early loves and how he met Vera, his working life and the dislocation of moving from Europe to the USA.

Eventually Maarten is placed in an institution. At some level he is aware of people around him, describing them as 'drugged it would seem by the way they sit staring in front of them at the whitewashed wall'. But his ability to construct meaning becomes more and more limited. The descriptions become more fragmentary.

The questions raised in this book are not just about dementia: Bernlef is interested in how we all make sense of the world and in what leads to our sense of identity. At the end of the book, as Maarten's grasp of the world fades away, he can no longer make sense of the information he is given. He hears the voice of a woman, who we assume is Vera, telling him that spring is almost beginning; but he no longer recognises her.

\section{Iris: A Memoir}

In the UK, the best-known account of Alzheimer's disease is the biography of Iris Murdoch written by her husband, the Oxford University academic John Bayley. Iris is a strange and exotic story of love and illness, not just because Iris Murdoch was one of the best-regarded post-war British novelists but also because of the milieu in which she and John Bayley lived. They met and courted in post-war Oxford, in what now seems a completely different world. Iris Murdoch is described as a exotic bohemian creature who had little regard for the sexual mores of the time. She was a bright student who studied and later taught philosophy at Oxford University. John Bayley was, by his own account, a rather socially awkward man who fell in love with her and had to adapt to her lifestyle.

Memory loss is the key to dementia and is central to this book, which is described as a memoir. Although there is sadness in the story it is also a celebration of a life and of world-class achievements. Their life together is detailed and the book is shot through with poignant examples of how Iris's past life relates to her condition at the end:

'She does not know she has written twenty-seven remarkable novels, as well as her books on philosophy; received honorary doctorates from all the major universities; become a Dame of the British Empire.'

Throughout their marriage the couple loved to swim, particularly in fresh water, Iris often naked. The book begins by describing the two of them going for a swim, contrasting the ease and naturalness of what used to be with the difficulties of the present dealing with someone who has dementia:

\footnotetext{
'Once we would have got our clothes off as soon as possible and slid silently into the water ... Now I had quite a struggle getting Iris's clothes off ... She protested, gently though vigorously, as I levered off the outer layers.'
}

John first realises that something is wrong when Iris is in Israel, taking part in a discussion at an 
international conference. She suddenly finds it difficult in front of a large audience to come out with the words to reply to questions, something with which she has previously been quite at ease. Although Bayley does not explicitly say that he knows what the diagnosis is at that time, he knows that this is the start of a serious problem. That moment is encapsulated dramatically in a prestigious literary setting. Many carers of people with Alzheimer's similarly recall such moments, perhaps in more mundane settings. Often it is only in retrospect that they realise that changes have been building up over time. For John Bayley, this moment triggers the realisation that some odd remarks Iris had made a few months before about a character in one of her books had a significance he had not understood at the time. The comments were in fact a clue that she was developing Alzheimer's disease.

As the illness progresses, the diagnosis is confirmed and there are referrals to hospitals by 'our own friendly harassed GP'. This area is covered only briefly and the role of the medical profession is that of simply confirming the diagnosis. Then the offers of help from friends, from professional helpers, come in. To Bayley these offers are an intrusion into a very private relationship. For example, he writes 'let us postpone it while we can' and 'I'm never absent so that carers are not now needed'. What is striking, and what we may sometimes forget, is the continuing pleasure that John and Iris take in their relationship. An unusual example of this is their routine of watching the Teletubbies, a television programme aimed at young children. Every morning, John would switch on the television set and this eccentric old-fashioned couple, who had never really been television watchers, would take delight together in a strange children's world.

At this juncture in the book it gradually becomes clear that Iris's mother had had Alzheimer's disease and ended up a nursing home. Bayley knows through personal experience the course of the illness and is determined to postpone this for Iris as long as possible.

As he realises that he is finding it increasingly difficult to care for Iris, inevitably guilt emerges he senses a reproachful look in Iris's face when he leaves her for an hour with a friend. As the illness progresses he is able to share less and less with Iris, the Teletubbies no longer interests her and he is unable to gain any insight into what she is thinking. The frustration and anger of dealing with someone with Alzheimer's disease gradually come to the fore. With the honesty that characterises Bayley's telling of their early courtship he chronicles his despair and anger, which is paralleled by his sense of isolation as the identity of the person he has shared his life with diminishes. He documents his rage, which spills over at Iris's continual overwatering of some house plants of which he is fond.

The book ends with a description of the events of Christmas Day 1997. Iris has become totally dependent on John. They have been invited to his brother's house in London, and there is an elegiac account of their walk around the city, the comfort of a familiar ritual. Illusion sustains John and the book ends not on a note of despair, nor in unjustified optimism, but with a dignified acceptance of the illness.

There have been accusations that John Bayley's account of his wife's illness is unjustifiably intrusive. It was published while Iris was still alive, but at a stage in her illness when she would have been unable to appreciate what had been written about her. The most vociferous voice in this debate is that of A. N. Wilson, who has just published his own biography of Iris Murdoch (Wilson, 2003). In this book, Wilson has declared himself 'sickened' by Bayley's frankness about the 'intensely private' Iris and accuses him of being a 'screaming hate-filled child'. There is no doubt that Bayley's account of his wife's dementia and the portrayal of her towards the end of her illness are sometimes uncomfortable for the reader, and there is a sense of prying uninvited into her life. I found myself frequently unsympathetic to both John Bayley and the milieu in which he worked and lived. However, whether Bayley was any less justified than other biographers in 'using' his wife as a subject for a book is a moot point. Unfortunately, this debate has degenerated into a classic literary feud which is being documented in the literary pages of British newspapers (Taylor, 2003).

Writing about a person who has dementia and who may not be able to understand or reply to what is being said about him or her is a complex moral issue. If it is acceptable to publish an account of someone's dementia (whether alive or dead) then the debate becomes about the degree to which the illness can be described, and this makes it very difficult to make a judgement. I do not believe that Iris would have benefited if Bayley had waited for her to die before publishing his biography of her, and what her own wishes would have been is impossible to know. From the point of view of the wider debate around dementia, however, there is no doubt that John Bayley's account, whatever the motivation for writing it, has helped to encourage a more honest discussion of the effect of this crippling illness on sufferers and those who care for them. 


\section{Remind Me Who I Am, Again}

This is the story by Linda Grant of the dementia of her mother, Rose (Grant, 1998). Like the other books here, it is much more than a factual account of an illness. Linda Grant's grandparents were Jewish refugees who fled Eastern Europe for the USA, but were tricked into ending up in England. The book is the account of how Linda and her sister, Michelle, coped with their mother, but also how they came to terms with their cultural heritage. Rose Grant had multi-infarct dementia and, as befits a book by a Guardian journalist, there is a good factual account of the illness and its symptoms.

The origin of this book was an article that Grant wrote for The Guardian newspaper of her battles with the bureaucracy of social services and that grew into a history of her family. As her mother's memories faded, Linda struggled to keep them alive. 'I don't know if it's a tragedy or a blessing when Jews, who insist on forgiving and forgetting nothing, should end their lives remembering nothing', she says of her mother. As her mother's short-term memory fades, memories of her childhood start to come flooding back. Ironically, these are the very recollections that Linda dismissed as boring family tales when she was a child growing up in the Liverpool of 1960s' Beatlemania.

For Linda Grant the point of realisation that there is something abnormal going on occurs when she is sitting in her mother's flat in Bournemouth and Rose is repeating over and over that she wants Linda to have some sundae spoons. The difficulties the daughters have in their relationship with their mother cloud their recognition of the development of the illness and this in turn feeds into their guilt. On one occasion while staying with Michelle and her boyfriend, Rose has tantrums and runs out of the house, ending up in a cheap hotel. Only gradually do Linda and Michelle realise that the increasing arguments that their mother is having with them represent something more sinister than selfishness. In 1990, Linda takes her mother for a holiday in Sorrento:

'The week in Italy was the last time that life was, for her, what it was supposed to be.'

The book is a chronological account and in it we can see a disease take shape. For professionals in old age psychiatry the story is one we instantly recognise. But for each carer it is a new experience, a revelation. First, there is a depressing encounter with a general practitioner: 'Old people forget things,' he says dismissively, 'my own mother forgets things.' Then comes a trip to Harley Street to see a specialist, which is when Rose is diagnosed with multi-infarct dementia. The diagnosis itself is a relief to the two sisters, as they have a name onto which to hang the problems that their mother has been experiencing. For example, the specialist tells them that 'the long held grudges about grandchildren or bad daughters had nothing to do with anything'. At that point Linda and Michelle 'take on the might of the system' and experience a depressingly complete lack of coordination between health and social services.

There is some discussion of the moral issues around forcing elderly people into long-term care and Grant makes the point that

'My mother's rights are allowing her to spend twenty-three hours alone, over-dosed or undermedicated, and crying.'

Whether one believes this to be the case or not (and Roses's situation was by no means as bad as that in which many patients with dementia who are alone find themselves), the anguish and powerlessness felt by carers is impressively described.

For many writers institutionalisation is the coda in describing the course of dementia, partly because once a person is in a home it must seem like the end. Because Rose is Jewish the process of finding a home is made simpler because of an organisation called Jewish Care. However, Linda Grant finds herself up against the rules of social services funding and, as with many carers, there is a sense of incomprehension about the rules that govern whether an individual can go into residential care.

The horror of the family in placing their mother in a home for people with senile dementia is striking: Grant's initial response is 'they've chosen the wrong place, she can't possibly stay here'. As she says, it is not the staff who are a problem - it is the other residents:

'The problem, and it will take ... a little time to work this out, is that it is not about who our mother is but who we want her to be.'

The painful progress in understanding this lies at the core of the book:

'We were our mother's gaolers ... we felt guilty ... My mother would never lose her rage at the place to which she had been delivered. She wanted to still be in the world, in the land of the living.'

The staff who take Michele and Linda 'through the door marked reality' are warmly described by Linda, although for both sisters this is a difficult and distressing time. The guilt that they 
feel is emphasised by the social expectations of others:

'I observed there was a gold standard of attendance by relatives to the home, which I fell far short of.'

It is only after John Bridgwater, who heads Jewish Care, points out that she is seeing her mother far more often than she would have done before and questions who is benefiting from the visits that she is able to begin letting go. Linda Grant's accounts of the conversations she has with him and other staff are a major part of the sisters' coming to terms with the situation. They read like accounts of psychotherapy sessions. Grant realises that she does love her mother, but not like those who say

'"I love my mother. I could never put her in a home." For loves are like people, each is different.'

The issue of Jewishness and how Rose's illness made Linda face this is a major theme of the book. Grant writes:

'All communities are to do with memory and none more so than the Jewish community in which everything is about what was.'

\section{Scar Tissue}

The Canadian writer Michael Ignatieff's account of his mother's decline into dementia comes from a different perspective. This is a novel, although the book is based on Ignatieff's own experience of the death of his father and illness of his mother. He has stated that he is 'not the son who gave up everything to be with his mother', who is the narrator of the book, but 'the brother at a distance'. This is a powerful novel, in which the mother's illness triggers a crisis in the personal life of the son at its centre. It is a passionately told story, with elements of both philosophy and popular science. The narrator, and it is hard at times to believe that this is not the author, justifies his telling of the story as a way of diminishing the memory of his mother's death 'by going back to the beginning'. As the story develops, intimations of what is about to happen begin to intrude. The mother suddenly abandons painting - her main interest in life - with no explanation, and the narrator immediately blames his father. But in the telling of the story he begins to understand how his parents love each another and to question the anger that he has directed at his father. Imperceptibly his mother changes - instead of waiting for family meals to finish of their own accord she begins to clear the table while people are still eating. There is an accumulation of incidents - first she loses her glasses, then her shoes; next, pots are left boiling on the stove. The narrator believes that his mother must have some insight and that she must at some point have understood what was happening to her.

As one would expect from an intellectual like Igniateff, the book is full of philosophical musings. At one point the narrator becomes fascinated by the idea that a positive mental attitude could help his mother to get better, as propounded in numerous best-selling books:

'I longed to believe that my mother was holding back the force of the illness with the power of her will.'

But he realises that this is not true, and concludes that a stoical attitude to the inevitability of death, rather than a pretence that it can be cheated, is the only appropriate response.

Ignatieff is clearly interested in what dementia does to the identity of the sufferer and he muses on the case of de Kooning, the famous American painter who developed Alzheimer's disease and yet continued to paint. This case raises all kinds of issues about where artistic creativity comes from: is it from conscious self-awareness or from a deeper, primal level? When the mother is severely demented the narrator puts some charcoal into her hand and despite her illness she manages, just, to draw a likeness of him.

The two brothers represent the polarisation that the narrator sees in his parents' marriage. On the one hand there is the doctor brother who, like his father, is a scientist, and on the other the narrator, a philosophy lecturer who, like his mother, has a background in the arts. The narrator believes that his father thought of him as having a 'scatty female mind, interested in gossip and personal details and stories'. The tension between the narrator and his father permeates the book. This polarity of world views is evident when the mother is taken to hospital to see a neurologist, who is described as seeing 'a disease of memory function, with a stable name and a clear prognosis'. For the narrator, it is different and he says 'I see an illness of selfhood, without a name or even a clear cause.'

After the death of their father the two sons have to put their mother in a nursing home, the narrator's brother coming down from Boston so they can 'share out the guilt'. However, as in Linda Grant's book, the guilt of placing a parent in long-term care is inescapable. The last thing his mother says to the narrator when he leaves her in the home is 'Get Out.' His next visit - he times it - lasts 7 minutes. 


\section{Box 1 Why literature has something to say about dementia}

These novels give their authors a chance to muse on memory and the role it plays in what we know about a person.

Doctors need to have a certain amount of detachment in order to deal daily with illness. Literature gives an opportunity to lose that detachment in a safe way.

Clinicians see patients and their carers at crisis points in their lives, whereas literature highlights the continuity of people's lives.

Our role is often seen as peripheral in an illness in which medical intervention is limited.

Although authors write from a particular perspective, they are able to point out universal themes.

Even when their mother is in the nursing home there are still moments of happiness, albeit brief. The two brothers take her on a car trip. During the journey they start singing a Danny Kaye song from their childhood; they cannot remember a rhyme, but their mother is able to complete it. The narrator is suddenly drawn to the past, to a time when the whole family were helpless with laughter, singing the same song together. The doctor brother is fascinated in a clinical way by her response, and yet he confides,

'the thing that matters most to me, the thing that actually makes me believe I exist is the fact that an old woman who lives in a nursing home recognises me.'

The doctor brother has a research interest in dementia and takes the narrator to his laboratory, where he shows him, through an electron microscope, a section of brain from someone diagnosed with Alzheimer's disease. There the narrator sees the characteristic neurofibrillary tangles and an amyloid deposit, the scar tissue of the book's title.

At the end of the book, when the narrator is told that he has cancer, he asks:

'Does understanding anything make a difference, if there is nothing you can do to stop it happening? An excellent question and one an entire life of introspection does not enable me to answer.'

\section{Conclusion}

It is a long time since Alois Alzheimer published his famous account of a patient with what came to be called Alzheimer's disease (Alzheimer, 1907). Although Alzheimer had also worked on vascular dementia previously, it was not until Hachinski's work three-quarters of a century later that the term multi-infarct dementia was introduced (Hachinski et al, 1974). As we have learnt more about the dementias and their prevalence has increased, people have become more willing to talk about them. But stigma is still attached to these illnesses and the situation with regard to dementia is similar to that which surrounded the discussion of cancer - and even the use of the word - several decades ago (Harpham \& Hoel, 1997).

There is no doubt that there is an increasing amount of literature published in which dementia and its consequences are discussed, and a good list of novels, plays, poetry and short stories can be found on the Alzheimer's Association website (http://www.alz.org/resourceCenter/ Resources/rtrlnov.htm). For carers dementia is, above everything else, a disease of memory and, understandably, the nature and character of memory is a preoccupation in these writings. For my four authors, dementia is an illness that destroys the person and ultimately confirms the centrality of memory to human life.

What do such books offer clinicians? All doctors work within society and need to understand how the population at large see the conditions they work with. Although the authors I have discussed have all offered a very personal and particular perspective on dementia, they also reflect how the wider world views this condition. Common themes, as one might expect, are of the nature and loss of identity and of carer guilt. Box 1 highlights some reasons why clinicians might want to read literary accounts of dementia. Most old age psychiatrists will not be surprised by the content of these books: they are familiar from our day-to-day working. What they do reveal, however, are perspectives on dementia completely different from our own. Reminding ourselves of this will surely help us to be better doctors.

Linda Grant explains why she chose to write about her mother's illness:

\footnotetext{
'Because there is a silence, a taboo. No one knows how to feel, or what to think because the meteor of dementia that strikes families and wipes out so much is supposed to be part of the realm of privacy.'
} 
These books collectively have helped the process of breaking the taboo.

\section{References}

Alzheimer, A. (1907) Uber eine eigneartige Ehrankung der Himrinde. Allgemeine Zeitschrift für Psychiatrie, 64, 146148.

Bayley, J. (1998) Iris: A Memoir of Iris Murdoch. London: Abacus.

Bernlef, J. (1988) Out of Mind. London: Faber and Faber.

Day, E. \& Smith, I. (2003) Literary and biographical perspectives on substance use. Advances in Psychiatric Treatment, 9, 62-68.

Eynon, T. (2002) Cognitive linguistics. Advances in Psychiatric Treatment, 8, 399-407.

Grant, L. (1998) Remind Me Who I Am, Again. London: Granta Books.
Hachinski, V. C., Lassen, N. A. \& Marshall, J. (1974) Multiinfarct dementia. A cause of mental deterioration in the elderly. Lancet, 2, 207-210.

Harpham, W. S. \& Hoel, D. (1997) Raising the curtain on cancer. Is the puzzle finally becoming clear? Postgraduate Medicine, 102, 232-236.

Ignatieff, M. (1993) Scar Tissue. London: Chatto \& Windus.

Murray Parkes, C. (2003) Invited commentary on: Death and dying in literature. Advances in Psychiatric Treatment, 9, 219-220.

Oyebode, F. (2003) Autobiographical narrative and psychiatry. Advances in Psychiatric Treatment, 9, 265-271.

Sims, A. (2003) Invited commentary on: Death and dying in literature. Advances in Psychiatric Treatment, 9, 217219.

Skelton, J. (2003) Death and dying in literature. Advances in Psychiatric Treatment, 9, 211-217.

Taylor, D. J. (2003) They knew her too well. The Guardian, 26 August.

Wilson, A. N. (2003) Iris as I knew Her. London: Hutchinson.
NOTICE TO SUBSCRIBERS

\section{Don t forget to renew your subscription}

to

Advances in Psychiatric Treatment for 2004

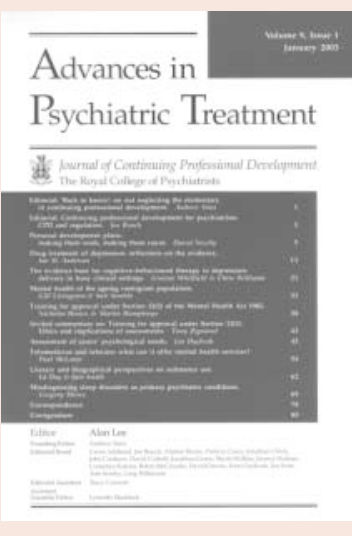

2004 subscription prices can be found at www.rcpsych.ac.uk/publications/apt_info.htm
Subscriptions Department, Maney Publishing,

Hudson Road, LEEDS, LS9 7DL, UK.

Tel: + 44 (0)113249 7481. Fax: +44 (0)113 2486983 .

Email: subscriptions@ maney.co.uk 